\title{
An Analyisis of Twitter Discourse on Xenophobia in South Africa
}

\author{
Abraham van der Vyver \\ IIEMSA \\ Ruimsig, South Africa
}

\begin{abstract}
In this paper the researcher will report on the history of Xenophobia in post-apartheid South Africa. This will be followed by a Twitter analysis of the discourse around the outbreak of Xenophobic attacks in September 2019. The nVivo12 software package was implemented to conduct a thematic and discourse analysis on 3784 unique tweets. The tweets were mostly condemning the attacks with many calling for a peaceful solution. Another trend was the relatively low number of tweets posted by the traditional media.
\end{abstract}

Keywords: immigrants, refugees, migrant labourers, attacks

\section{Introduction}

Xenophobic violence has been plaguing post-apartheid South Africa since 2008. It struck again in September 2019 when least 12 people were killed in recent weeks after 1,000 foreign-owned business were targeted [1]. Most of the victims were Nigerian. Nigerian Airlines are in the process of repatriating more than 600 refugees who felt their lives are in danger in South Africa [2]. Foreign workers in South Africa - the continent's second-largest economy after Nigeria - are often victims of anti-immigrant sentiment in a nation where almost one-third of people are unemployed.

A South African envoy apologised "profusely" to the Nigerian government after the deadly xenophobic attacks in Johannesburg and Pretoria. In a statement released by the The Nigerian government announced that "President [Muhammadu] Buhari responded to profuse apologies from the South African president, pledging that relationship between the two countries will be solidified"[1]. The Nigerian government nevertheless announced it would repatriate more than 600 nationals to protect them from future violence. The violence prompted revenge attacks against South African firms in Nigeria and the temporary closure of South Africa's diplomatic missions in Lagos and Abuja [3].

The unfortunate attacks were not only directed at Nigerian nationals. Hundreds of shops were looted and burnt to the ground. Many shop owners who suffered major losses were from Pakistan and India. More than 700 people from other countries, including Malawi and Zimbabwe, sought refuge in South African community centres [3].

\section{Literature}

Harris described xenophobia in the International Encyclopedia for "literally "the fear of strangers," xenophobia is the targeting of foreigners and estranged citizens for stigmatization, discrimination, and scapegoat-ing within nation-states. Xenophobic hostility and violence arise in multicultural contexts in which established constructs of national identity are in [4] 
Xenophobia exists all over the world. South Africa is no exception. As early as 1998 the Human Rights Watch report raised an alarm that immigrants from Mozambique, Zimbabwe, and Malawi who were living in South Africa were brutally attacked during January 1995, "in what was called Operation "Buyelekhaya", (go home); a clampdown that claimed to 'clean' some South African townships of foreigners" [5]. It erupted again in 2008 when refugees and migrant workers were attacked. "The rationale was that foreigners were culpable for "increased crime, sexual attacks, economic deprivation, unemployment, disease and all manner of social ills" [5]. Despite the constitution's guarantee of the human rights for all, some local politicians have "made use of xenophobia to mobilize poor people against migrants in the struggles for space, jobs and other resources" [6]. Researchers also found that different dimensions of violence are effected on different nationalities. The 2013 attacks were for instance mostly aimed at Somali entrepreneurs [5].

Connections between racism and xenophobia are addressed in the Durban Declaration and Program of Action, which was discussed at the 2001 United Nations World Conference Against Racism, Racial Discrimination, Xenophobia, and Related Intolerance held in South Africa. Harris pointed out that the differences between these two constructs often become blurred, she explained that "(i)n the contemporary era, racism is often subtle and the concept of "race" encoded in a public rhetoric of culture rather than in a biologically determinist notion of categorical and hierarchical difference [4]. The rights of migrant workers, refugees, and asylum seekers remained a top priority at the Geneva-hosted Durban Review Conference in 2009. A human rights approach to global migration governance has continuously been advocated, consistent with the vision expressed in the International Convention on the Protection Rights of All Migrant Workers and Members of Their Families, adopted by the General Assembly of the United Nations in 1990 but not entered into force until 2003 [4].

\section{Methodology}

A case study approach was followed to investigate the Xenophobic attacks of 2019. Zainal [7] explained that an interpretive case study takes place when "the researcher aims to interpret the data by developing conceptual categories, supporting or challenging the assumptions made regarding them."

A total of 3784 unique tweets were captured with nCapture from \#Xenophobia on Twitter during the crisis. The nVivo software package was then used to conduct a stakeholder and thematic analysis was conducted on all the tweets.

Bakker [8] explains that the "non-hierarchical nature of social media" allows fast public responses and helps facilitate the public to communicate with each other, which in turn helps researchers get a better understanding of the public opinion.

\section{Analysis}

\subsection{Themes}

The following themes were identified in the Twitter analysis. Each theme is illustrated by one or more tweets:

Murder

\#Xenophobia \#Murder the African way

Shock

I am totally appalled by South Africans justifying xenophobic attacks perpetrated by her citizens, there is nothing as painful as them thinking that their actions are right.

Drugs 
So SA'ns go on the rampage because foreigners sell drugs to kids. But now SA'ns celebrate the return of a convicted drug mule \#NolubabaloNobanda

\#XenophobiaSouthAfrica

Lawlessness

We are not xenophobic we just don't want lawlessness https://t.co/7BmaMZTDXy

Double standards

@devan_murugan@eNCA @YouTube However if the protesters had attacked white/foreign owned businesses, Moody would have downgraded their status. Attacking a few businesses owned by black Africans means nothing.

We keep repeating that we not xenophibic but won't tolerate lawlessness https://t.co/GsLHHvYPKe

Denial

Xenophobia indicates deep hatred for anything foreign. I don't believe this is the case in South Africa. Before the attacks, I am positive the foreign shops in SA caters to both locals and foreigners which negates the concept of xenophobia.

Jest

My fellow South Africans watsiba we forget most bouncers are Nigerian so just wondering how our weekend gonna go... random thoughts nothing else \#XenophobiaInSouthAfrica https://t.co/rCGaD9g5na

Fingerpointing

All because a Nigerian drug dealer shot \& killed a South African taxi driver, this is what happens when you fuck up someone else's country \&amp; show no respect to its citizens.\#XenophobiaInSouthAfrica

\#XenophobiaInSouthAfrica Nigerians remember when you deported 2 million Ghanaians, it looks like they have not forgotten, there are possible xenophobic attacks coming in Ghana against Nigerians, so buck up guys https://t.co/UN7YrfhUI2

Retribution

The rest of Africa should refuse to deal with South Africa. That country should be left alone and kicked out of the AU. Africa was, is and will be better off without South Africa \#XenophobiaInSouthAfrica

\#XenophobiaInSouthAfrica must stop or we take south Africa out of AFRICA.

Ubuntu (goodwill)

\#XenophobiaInSouthAfrica

Let us all embrace UBUNTU

We are one Nation

Empathy

\#XenophobiaInSouthAfrica safa saphela isizwe sase mzansi, i now know what it feels like to feel hopeless when your country is attacked and your leadership just ain't entertaining, I now understand a bit of what they felt 
when singing this song https://t.co/mj7MtmMB3S

Anguish

\#XenophobiaInSouthAfrica sad sad when when a brother kill a brother on the same continent!!

Entitlement

Your countries helped us get rid of apartheid, does that give you a right to come sell drugs and destroy the moral fabric of our society?

I feel some people are so entitled way more than the natives.

\#XenophobiaInSouthAfrica

Colonization

There's a reason \#SouthAfricans were colonized for several decades longer than other Africans. And, with \#XenophobiaInSouthAfrica, it's easy to see it!

Crime intelligence

@SAfmnews Kodwa says they were able to prevent an outbreak of violence in Bloemfontein through their intelligence last night. He has dismissed claims that intelligence has failed foreign nationals. \#SAfmSunrise \#SayNoToXenophobicAttacks \#XenophobiaSouthAfrica \#sabcnews \#SAfmnews

Plea

South Africans must arise above the evil that continues to reside and thrive in their hearts. The evil that misleads them to think that they would have been doing fine if there were no other africans from other countries taking their jobs. \#XenophobiaInSouthAfrica

Xenophobia - Time for Cool Heads to Prevail in Nigeria and South Africa: https://t.co/BUCO7ekr3S \#SouthAfrica \#Nigeria \#Xenophobia \#XenophobiaSouthAfrica \#XenophobicAttacks https://t.co/yV0nUUCR9Q

\subsection{Stakeholders}

The following stakeholders were identified in the tweets. In some cases they were actually responsible for the posting of the tweet.

\section{Stakeholders}

Nigerians

Nigerians need to ask themselves why so many countries want them out, why so many of your people are accused of drug dealing, being drug mules or scammers, you see the speck in your brother's eye but not the beam in your own. Fix yourselves first \#XenophobiaInSouthAfrica

All we need is a paradigm shift. Nigeria stand for peace and unity every where we go. We really need to understand that war or burning down their business will stop them from their evil acts. Nigeria Government should dodneed full and let peace reign. \#XenophobiaInSouthAfrica

\section{SA Government}


Some of the reasons why LAND WITHOUT EXPROPRIATION never got successful is that the South African government is trying to accommodate people who are not South Africans yet african and they not our responsibility \#shutdownsouthafrica

Mozambique government

\#BREAKING: Following \#Nigeria's lead \#Mozambique condemns \#XenophobiaInSouthAfrica and looks to repatriate Mozambique nationalsUN

Human Rights Commission

Just wondering if the @UN@UNHumanRights@antonioguterres@hrw actually addressed the black on black crime known to many as \#XenophobiaSouthAfrica.. i'm Jst asking

The Police

Police do your job, that's the only way you'll stop this hate amongst Africans

@casspernyovest@akaworldwide@iam_Davido@burnaboy@Marazamc@MbalulaFikile @SAPoliceService @eNCA \#XenophobiaInSouthAfrica

"Merely condemning xenophobic violence is not enough to stop it - the police should thoroughly investigate, arrest, and bring to justice the attackers." - @ dewamavhinga https://t.co/osVyEbsLU7 \#XenophobiaSouthAfrica \#XenophobiaInSouthAfrica \#Xenophobia

Citizen journalists

We must strongly condemn hate, prejudice and xenophobia and reiterate our unequivocal condemnation of all violence.

@ Beatitudes1040 South Africans stop this weakness and you all should not forget so soon how other Nations in Africa came to your aid when it was needed. We all can still live as one. God bless Africa and no place else. \#SayNoToXenophobia https://t.co/jX4HdxUCJ1

Bob Marley

My love for my people is stronger than anyone's hate - Bob Marley I'm surprised that this \#XenophobiaInSouthAfrica is still trending

Media

Horn Globe

South Africa's Former Minister appointed to address xenophobic attacks

\#XenophobiaSouthAfrica \#SouthAfricans https://t.co/3k5rKXbgqy https://t.co/Fg8C3kEDUT

iol

@IOL And so we should say nothing and do nothing, for fear of being \#XenophobiaSouthAfrica ?

Nah man our media houses are failing us. Such a story as this should go viral as the xenophobia nonsense.

EWN

of ${ }^{\lambda}$ FAKE NEWS: Here are all the videos that are NOT from the xenophobic attacks. \#XenophobiaSouthAfrica https://t.co/KkfZSaAq7T

The Star 
@TheStar_news Children shouldn't see fellow Africans as enemies

Carte Blanche (A very influential prime time investigative television program)

[WATCH] Chaos on the streets of Gauteng as angry mobs burn cars, loot shops and attack foreign nationals. @Devi_HQ examines why xenophobic attacks continue to flare up in South Africa. \#CarteBlanche

UrbanRadio45

Photo News:South Africa President sends his Envoy to Nigeria to apologise over Xenophobic attacks. @UrbanRadio945

Interest groups

The Chairman/CEO, Nigerians in Diaspora Commission Hon. Abike Dabiri-Erewa, now holding a World Press Conference in her office for updates on the Evacuation of Nigerians from South Africa as we expect the second batch of returnees.

Unlikely

DietitiansZA stands against any form of xenophobia. We are one nation, one nutrition one love. Hand off our foreign national brothers and sisters

SA Refugees (Nigerians going back to their home country)

Governor @jidesanwoolu yesterday at Muritala Mohammed International Airport received 315 South Africa Returnees and presented them with gifts.

Ramaphosa

\#Mugabe funeral - SA leader @CyrilRamaphosa booed over \#XenophobiaSouthAfrica, apologizes for the xenophobic violence in SA \& the crowd cheers, says he understands what is being expressed by the crowd.

Ace Magashule

\#XenophobiaSouthAfrica phobiaSouthAfrica ANC secretary general Ace Magashule says the assistance of citizens will go a long way in helping put a stop to the recent violence seen over the past few weeks. MEM

\section{Conclusion}

The results of the data analysis give good insights into the public opinion on the 2019 Xenophobic attacks in South Africa. The stakeholder analysis rendered tweets by and/or on countries/organizations/individuals that were involved in the unfortunate events. In that respect these stakeholders form the public part of public opinion. The opinion part are embedded in the thematic analysis.

Although the digital divide causes the array of opinions shared by the Twitterati lacks perfect representivity, it reflects the opinions of stakeholders who care about the topic. This is not always the case with conventional opinion polls.

The majority of tweets condemned the attacks and/or called for a peaceful solution to the crisis. Another trend was the relatively low number of tweets posted by the traditional media. 


\section{References}

[1] Aljazeera, "South Africa offers 'profuse' apologies to Nigeria after attacks," 18 September 2019. Available: https://www.aljazeera.com/news/2019/09/south-africa-apologies-nigeria-xenophobic-violence-190916174014436.html

[2] Aljazeera, "Nigerians repatriated from South Africa after attacks," 12 September 2019. Available: https://www.aljazeera.com/news/2019/09/nigeria-begins-repatriate-nationals-south-africa-190911074310949.html

[3] News24. "South Africa apologises to Nigeria after anti-migrant violence," 16 September 2019. Available: https://www.news24.com/SouthAfrica/News/south-africa-apologises-to-nigeria-after-anti-migrant-violence-20190916

[4] F.V. Harris, "Xenophobia”, in. Encyclopedia of Global Studies, M. Juergensmeyer, M, and H. K. Anheier (Eds). London, SAGE Publications, 2012, pp.1831-1833.

[5] P.O. Marumo, M. Chakale and A. Mothelesi. (May 2019). Xenophobia Attack and Development: A Discourse in South Africa. International Journal of African Renaissance Studies - Multi- Inter- and Transdisciplinarity. Special issue, pp.185-198. Available :- DOI: 10.31920/2516-5305/2019/v16n1a0

[6] O. Sichone, O. "Xenophobia", In New South African keywords, N. Shepherd and S. Robins (Eds.), Johannesburg, Jacana Publishers, pp.255-263.

[7] Z, Zainal, "Case study as a research method,".Jurnal Kemanusiaan, Vol.9, pp.1-6, 2007.

[8] F.D. Bakker, "Online activism, CSR and institutional change" Civic Engagement and Social Media: Political Participation beyond the Protest, J. Uldam and A. Vestergaard (Eds.), Basingstoke: Palgrave Macmillan, 2015, pp. 2343. 